\title{
Defiance, Persuasion or Conformity? \\ The Argument in Plato's Apology and Crito
}

\author{
MIKOLAJ DOMARADZKI / Poznań /
}

While the relation between the individual and the state belongs clearly to one of the most complex issues in Western political philosophy, the relation between the Socrates of the Apology and that of the Crito ranks, accordingly, as one of the most contentious problems in the entire Socratic scholarship. This is due to the fact that in the Apology (29 c-d) one is confronted with a defiant rebel who daringly challenges the established political order, whereas in the Crito $(51 \mathrm{~b}-\mathrm{c})$ one encounters a law-abiding citizen who meekly submits himself to the harsh judgment of the Athenian Laws. Thus, the two dialogues present the reader with the difficulty of somehow reconciling Socrates' belligerent repudiation of the state during the trial with his humble acceptance of the resulting death sentence.

If the Apology and Crito revolve around the perennial conflict between the private (tò '́oıvv) and the public (tò koเvóv), then their dilemma is whether, and if so, in what circumstances, the citizen is entitled to flout the laws of their state. Carried to its extreme, the doctrine of civil disobedience leads to the problem of "a city without laws (лó ávev vó $\mu \omega v)^{\text {"1. }}$. Clearly, if everybody could reject the state and its laws whenever they felt disappointed with these institutions, then the only possible result would be social disintegration and total anarchy, which, as Plato argues in the Republic (562 b - 564 a), would ultimately lead to tyranny. Hence, if we agree that civil disobedience should always be

${ }^{1}$ Cri. 53 a. 
the last resort, then the question is whether, and if so, to what extent, the doctrine can be attributed to Socrates. Before we attempt to answer the question, we need to first look at the incompatible views of $\lambda$ ó $\gamma$ os that Crito and Socrates subscribe to.

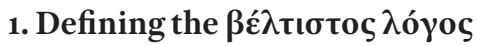

Let us begin with an observation that the Crito does not propagate the doctrine of citizens' unqualified obedience and absolute duty to the state ${ }^{2}$. Having asserted that one "must revere and give way to and fawn upon a fatherland", the Laws, nevertheless, do open another possibility for the citizen who must either do "whatever the city and fatherland bid, or else persuade ( $\pi \varepsilon i \theta \varepsilon เ v)$ it what the just is by nature"3. Whilst the alternative "obey or persuade" provides the citizen with right to question and correct the political establishment, the interesting question is obviously why Socrates remains impervious to any persuasion from Crito: if the Laws allow for the possibility of being persuaded, then why does Crito fail to persuade Socrates to disobey the state? The answer lies in the mutually exclusive views of $\lambda$ ó $\gamma$ os that Crito and Socrates opt for. This can be clearly seen, if we look at the litany of charges that the former brings against the latter.

\footnotetext{
2 Naturally, the issue is very complicated and difficult to settle. An emphasis on the respect for constitutional liberties in the Crito was already put by Gomme (1958: 47-48). Against this, however, Greenberg (1965: 64) did not know "where to begin in outraged protest against" the argument of the Laws. Dyson (1978: 432-436) tried to strike a happy medium between the two positions. More recent scholarship has not settled the issue, either. See in this respect Erler (2007: 119) and Wallace (2011: 91). Kraut, for instance, argues that the alternative "persuade or obey" is a crucial softening of the authoritarianism of the Crito. The scholar stresses that the political philosophy of the Crito "does not turn the individual into a servant of the state, in any significant sense; it does not demand blind obedience; and it does not tell the citizen to «love it or leave it»" (Kraut 1984: 6). While Kraut reconciles the Crito with the Apology by reading the alternative "persuade or obey" in such a way that it allows disobedience by means of persuasion, his account has met with robust criticism. For a criticism of Kraut's interpretation see Colson (1989: 29-31) and Bostock (1990: 14-16). Bostock's analyses lead him to belief (1990: 17) that "Plato did indeed mean to argue for the strong conclusion that one should always obey any and every law". Again, Brickhouse and Smith (1994: 154) sought the golden mean by characterizing the Laws as "more like a modest umpire or referee in a sport contest who recognizes his own fallibility as well as that of the players and who also welcomes attempts by players to persuade him whenever they believe that he has erred in a call". Another line of defense is to refrain from identifying the views espoused by the Laws with the view of Socrates. This option has been pursued by Weiss. The scholar observes that "If Socrates in the early part of the Crito is a man who obeys only the principles that result from his own reasoning and recommends the same course to others, then the personified Laws in the latter part of the Crito, who would have men obey absolutely the city and its laws, cannot represent Socrates" (Weiss 1998: 4). Cf. also Wallace (2011: 95). Nevertheless, some scholars have expressed their doubts as to the possibility of isolating the views of Socrates from the Laws' discourse. Thus, Vlastos (1995: 90) seems reluctant to “drive a wedge between the discourse of the Laws and Socrates' own opinion". For the scholar's criticism of "so un-Socratic a speech" of the Laws see Vlastos (1974: 518). Yet another approach has been proposed by Saccarelli (2007: 536-541). It has to be noted, though, that the "consistently and radically anti-political Socrates" that Saccarelli argues for (2007: 523 and 529) has already been anticipated by the first "existential" interpretation of Socrates that is to be found in Kierkegaard (1989: 157-218). The "father of existentialism" has arrived at the conclusion that "Socrates, in his relation to the established order of things, was entirely negative", for "against the established order of things, the substantial life of the state, his whole life was a protest” (Kierkegaard 1989: 217-218). A convincing criticism of Saccareli's position is offered by Jedan (2010: $3 \ln 1$ and 40-41).
}

3 Cri. 51 b-c. Translation by West and West (1984: 110). 
Crito launches into a vicious harangue against Socrates' position ${ }^{4}$. He notices ( $44 \mathrm{~b}-\mathrm{c}$ ) that in the event of Socrates' death he will lose not only a friend but also his reputation, since many people will think that he could have saved the philosopher, but was unwilling to spend the money. While Socrates does not gainsay the bereavement argument, he dismisses (44 c) Crito's concerns about his tarnished reputation by refusing to heed the opinion of the many. On the surface, the philosopher's disregard for the hoi polloi might seem well-founded, but now Crito cunningly retorts (44 d) that the "necessity" (ává $\gamma \kappa \eta)$ to actually care for the opinion of the many is evidenced by Socrates' "present situa-

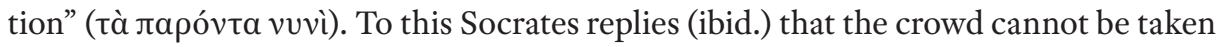
as an evaluation reference for a course of action, for the many act always on the spur of the moment ${ }^{5}$. This exchange of arguments reveals that Socrates refuses to recognize as rational what Crito acknowledges as such.

Thus, whether Crito appeals to Socrates' moral obligations as a friend (44 e) or parent $(45 \mathrm{c}-\mathrm{d})$, the philosopher turns a deaf ear to all these pleas and announces ( $46 \mathrm{~b}$ ) that he obeys exclusively the "best" ( $\beta \varepsilon ́ \lambda \tau ı \sigma \tau o \varsigma)$ argument ${ }^{6}$. Socrates' assertion leads us naturally to wonder what is wrong with the $\lambda$ ó $\gamma$ os that Crito makes use of: why will Socrates not yield to Crito's apparently rational arguments? The answer is that none of the arguments that Crito offers can pass as rational for Socrates, since Crito understands $\lambda$ ó $\gamma$ os in a manner similar to the Sophists: in lieu of a universal one, he proposes a $\lambda$ ó $o$ o that is determined by the present circumstances and expectations relating to future developments 7 . In other words, Crito perceives $\lambda$ ó ${ }^{\circ} \varsigma$ in terms of optimal actions that guarantee a successful performance. This is clear from his reproach of Socrates.

When Crito complains that the "trial came to court when it need not have done so", when he is mostly dissatisfied with "the handling of the trial itself" and its "absurd ending" " he evidently equates $\lambda$ ó o with an optimizing strategy: if an action is to be regarded as rational it must first and foremost be efficient. Hence, his bottom line is that if only Socrates had taken into consideration the circumstances and acted accordingly, the entire predicament could have been avoided. That is precisely why Crito points out

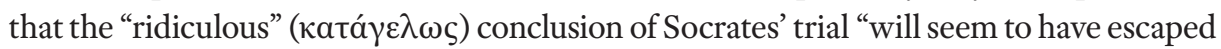

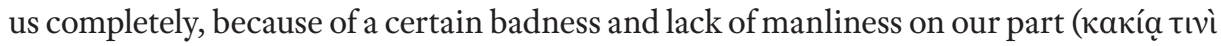

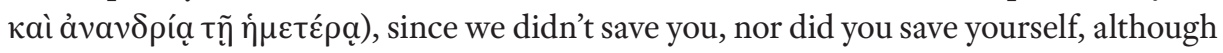

4 Crito's arguments have been arranged, presented and interpreted very differently. Good expositions are to be found in Zuckert (2009: 755-756), Erler (2007: 117-118), Beversluis (2000: 63-68), Weiss (1998: 39-53), Miller (1996: 122-123), West (1989: 72-73) and Greenberg (1965: 48-49). Beversluis (2000: 59-74) offers a very detailed portrayal of the historical Crito.

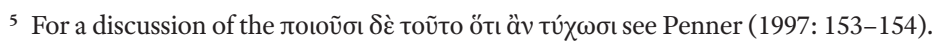

6 On the basis of the fact that in the Crito Socrates does not makes any reference to his divine sign, but

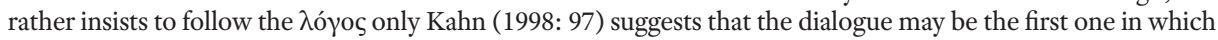
Plato, instead of basing philosophy on religious reassurance, begins to "construct a rational basis for his own Socratic commitment to the moral life". The same point is made by Erler (2007: 117). Cf. also Young (2006: 56).

7 Crito's pragmatism has often been emphasized. See e.g. Greenberg (1965: 50), Miller (1996: 132), and Beversluis (2000: 62).

${ }^{8}$ Cri. 45 e. Translation by Grube (1975: 46). 


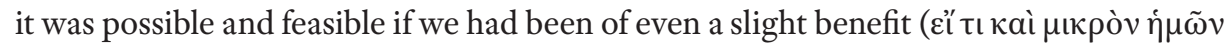

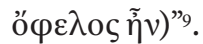

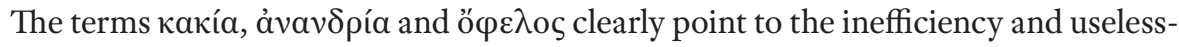
ness of the course of action adopted by Socrates and his friends. In Crito's view, the ends which need to be carefully assessed determine the means one resorts to in the course of one's actions. Thus, a given action is rational only if it is successful. That is why Crito wants Socrates to adapt himself to the present opportunities and institutional constraints. Without such an adaptation Socrates' actions will neither be efficient nor rational. Consequently, Crito would probably have agreed with Meno, a sophist and an interlocutor of another Plato's work, that there are diverse kinds of virtue, since virtue is always relative to the person's objective, age, and so on ${ }^{10}$. Summing up, we might say that Crito identifies $\lambda$ óyos with utility: having knowledge that in a given situation this particular course of action will result in achieving the desired goal, entails, for him, selecting this particular course of action as rational.

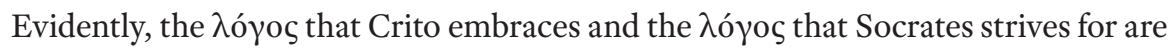
poles apart, since the latter does not want to equate utility with rationality, let alone with morality. In the Apology ( $31 \mathrm{~d}-\mathrm{e}$ ), Socrates remarks bitterly that if he had endeavored to participate in politics, he would have died long ago, proving thus to "have been of no use

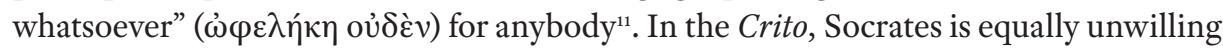
to stoop to the pragmatism that Crito and the Athenian democracy expect from him. Contrary to Crito, Socrates espouses no relativism, as for him $\lambda$ ó $\gamma$ os signifies a logical and moral coherence that is upheld irrespective of the circumstances. This is clear in his refusal to "now" ( $v \tilde{v} v)$ discard the previous arguments and in his perseverance to "venerate and honor the same ones" as before ${ }^{12}$. These utterances show that Socrates repudiates the idea that circumstances determine one's obligations. The philosopher is concerned only with how "the argument guides" (48c), and the guidance must be unaffected by the flux of time. Thus, while Crito looks for what is right at the present moment, Socrates wants to know what is always right, as the philosopher aims to find universally valid principles of conduct. That is also why when examining the argument Socrates asks whether "that was well-spoken before ( $\pi \rho i v)$ the necessity to die came upon him, but now ( $v \tilde{v} v)$ it is clear that this was said in vain for the sake of argument" and when he enquires wheth-

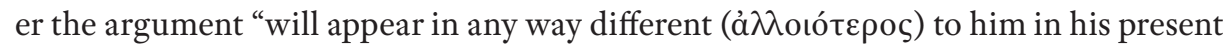
circumstances $(\tilde{\omega} \delta \varepsilon)$, or whether it remains the same” ${ }^{13}$. Contrary to Crito's fluctuating situation-rationality, Socrates' seeks, then an immutable $\lambda$ ó ${ }^{\circ}$ ৎ̧ lest the same action be

9 Cri. 45 e - 46 a. Translation by West and West (1984: 103).

10 Cf. Men. 72 a.

${ }^{11}$ Jedan (2010: 36) is clearly right in that Socrates' words are "eine harte Kritik, wenn auch vielleicht nicht am demokratischen Ideal, so doch zumindest an der täglichen Praxis der athenischen Demokratie”. Wallace, too, stresses (2011: 89) that Socrates in the Apology "condemns democratic courts and democratic government", whereas his speech "parodies democratic court speeches" (see also the references cited by the scholar).

12 Cri. 46 b-c. Translation by West and West (1984: 104).

${ }^{13}$ Cri. 46 d. Translation by Grube (1975: 46-47) slightly modified. 
rational and moral in one situation, but irrational and immoral in another. Accordingly, the philosopher stresses his determination to follow the imperative of such $\lambda$ ó $\gamma$ os irrespective of the vagaries of fate.

Socrates' vehement rejection of Crito' pragmatism and the implied relativism is important for understanding the political views of the Laws: the conflict between the $\lambda$ ó $\gamma$ os that is sensitive to the present opportunities and the $\lambda$ ó $\gamma \circ \varsigma$ that is not relative to the ever changing circumstances leads to the question whether there is a universally valid system of legal regulations that allows no exemption whatsoever. Thus, the exchange of arguments between Crito and Socrates leads ultimately to the question whether it is possible to avoid the doctrine of civil disobedience without at the same time condoning relativism.

\section{Discussing the $\pi \varepsilon i ́ \theta \varepsilon ı v$ option}

While in the Apology Socrates questions the laws of Athens, in the Crito the personified Laws question the position of the philosopher. The Laws ask Socrates (5o b) whether he wishes to "destroy" (áло $\lambda \dot{\varepsilon} \sigma a$ ) them and, thereby, the whole city, suggesting, that Socrates' disobedience would annihilate the whole legal system ${ }^{14}$. The argument seems to suggest that 1) no state is possible when the citizens disobey its laws and 2) even one act of defiance threatens the prosperity of the whole community, for if Socrates' escape were to become a norm, it would be the undoing of all normativeness. Now, if one maintains, as the Laws appear to do, that every single act of civil disobedience is socially destructive, since it undermines the authority of the state and, thereby, jeopardizes the integrity of the community, then one is left with the dubious conclusion that questioning the law is acceptable under no circumstances whatsoever: even if the law is wrong and unjust it has to be obeyed blindly.

Curiously enough, the Platonic Socrates is perfectly aware of the fact that unforeseen and unpredictable circumstances may nullify one's obligations. As has been stressed by Vlastos (1974: 529) ${ }^{15}$, Socrates in the first book of the Republic (331 c) puts it in no uncertain terms that one should not return arms to an insane friend. Thus, he does make allowances for the fact that one can be exempted from one's duty. Consequently, the interlocutors in the Republic reach the conclusion that no law or state is perfect: the ideal city they

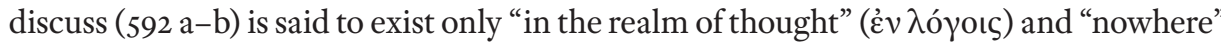

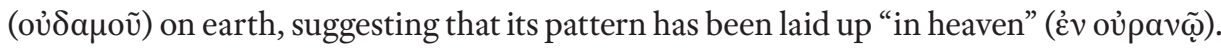
Socrates' defiance in the Apology can be taken as a manifestation of precisely such a "realistic", i.e. critical and revisionary, attitude towards the existing laws.

${ }^{14}$ Cf. Miller (1996: 127), Brickhouse and Smith (1994: 155), Bostock (1990: 2), Kraut (1984: 35 and 42), Dyson (1978: 428) and Barker (1977: 18 and 26).

15 See also Nails (2009: 8-9) who places the Crito in the context of Protagorean relativism. 
Suffice it to recall here his voting against the Council in the trial after Arginusae (32 b) or his rejecting the order of the Thirty $(32 \mathrm{c}-\mathrm{d})$. When the philosopher declares $(32 \mathrm{~d})$

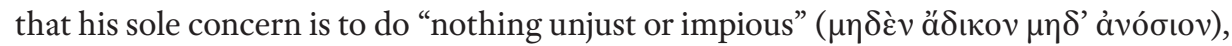
he does seem to advocate for a critical evaluation of the established political order: if the laws or the government are recognized as unjust or impious, then they can and should be repudiated ${ }^{16}$. Moreover, Socrates claims his actions to be divinely inspired. Thus, he characterizes his life and philosophy as a "service to the god"17 ${ }^{17}$, and explains that in living the life of a philosopher and examining himself and others, he follows the orders of the $\operatorname{god}^{18}$. Consequently, Socrates in the Apology values obedience to the god above obedience to the state and, accordingly, informs (29 d) the jury and thereby the state that he

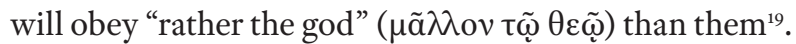

Does Plato in the Crito say that irrespective of the circumstances every act of disobedience against the state is always inadmissible? Is he in the Crito oblivious to the fact that no law or state is ideal? When trying to assess how realistic the Laws' portrayal of a good citizenship is, one should be very cautious lest the explicit defiance of the Apology cloud the implicit revisionism of the Crito. As already noted, the Laws do offer the alternative of persuasion, which entails that the citizens are not doomed to blind obedience and unconditional surrender to the state. While in the Crito $(51 \mathrm{~b})$, the Laws leave the citizen

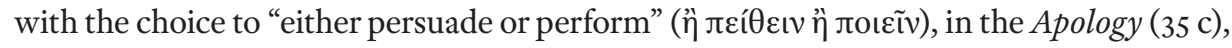

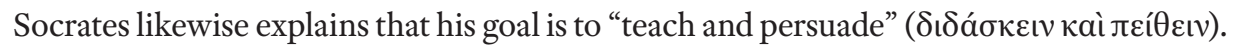
Thus, both the Crito and Apology allow for the possibility that the citizen may critically appraise the legal system of their city and propose some sort of amendment or modification of the existing law. While this was precisely what Socrates overtly did in the Apology, the possibility of rectifying the legal system surfaces clearly in the Laws' permission to $\pi \varepsilon^{\prime} \theta \varepsilon \imath v$. But this brings us back to the issue of relativism, for 1) when is that one can and/ or should persuade the state? and 2) how is one to achieve this?

At the beginning of the Crito, Socrates refused (44 c) to take into account the opinion of the many. Nonetheless, towards the end of the dialogue the philosopher is forced to heed the hoi polloi in order to justify his decision to obey the law. Thus, he observes (53 c) that in the event of escape he will be perceived as "unseemly (á $\sigma \chi \eta \mu o v)$ " and (53 e) that many "unworthy" (åvá Łıa) things will be said about him. Surely, then, living in a society compels one to care for the reputation one has among the many. The same concern for the opinion of the hoi polloi echoes the ominous prediction made by the Laws ( $53 \mathrm{~b}$ ) that

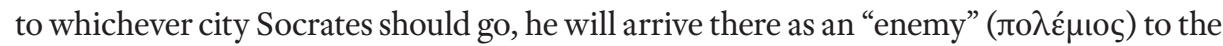

16 While Dyson (1978: 432-433) argues that the Apology cannot be taken at all as a call for civil disobedience, Colson (1985: 133-151) does interpret the Leon episode as an act of civil disobedience. See also Kraut (1984: 17-22), West (1989: 78), Bostock (1990: 18), Brickhouse and Smith (1994: 144-146 and 162-163), Weiss (1998: 13-15) and Nails (2009: 15-16).

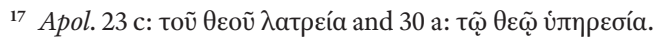

18 Apol. 28 e: $\theta$ coũ tátтovtos.

19 Jedan aptly points out (2010: 35-41) that Socrates' "religiös motivierte Pflicht" makes it impossible to recruit the thinker as a precursor of modern theories of deliberative democracy. 
government and that everyone who cares for their city will perceive him as a "destroyer"

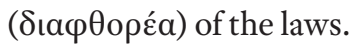

If the Apology and Crito admit the possibility of $\pi \varepsilon i \theta \varepsilon \imath v$, then it has to be borne in mind that the state is actually the many and, thus, persuading it entails wooing the hoi

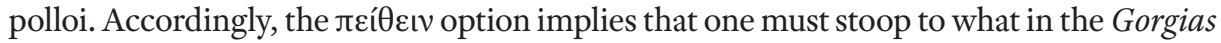

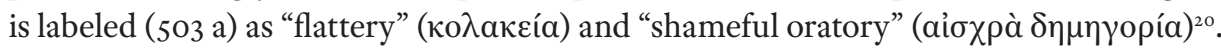
Furthermore, persuading the state requires from Socrates not only adulation, but also calculation of the odds and opportunities: in order to efficiently persuade, one must take into consideration the present circumstances and act accordingly. Here, as we have seen, Socrates is also uncompromising: the philosopher refuses to adapt himself to a particular situation, because he seeks a $\lambda$ ó $о$ os that will be unaffected by the vagaries of the fate and the whims of the crowd $(46 \mathrm{~b}-47 \mathrm{a})$. This is another point where the Crito and Apology concord. Thus, in the Crito, Socrates forcefully asserts (48 b) that the most important thing is not just life, but "the good life" (tò eṽ $\zeta \tilde{\eta} v$ ). The same point is made in the Apology,

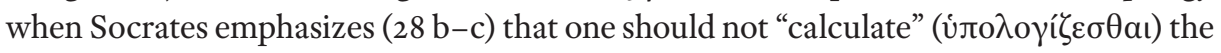
odds of winning, for people who reduce life to such calculations must view the heroes

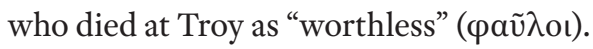

Notwithstanding these lofty words, Socrates can also purport (47 a) that one

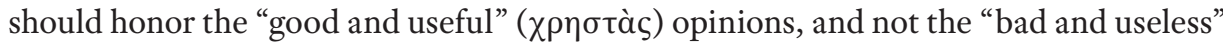

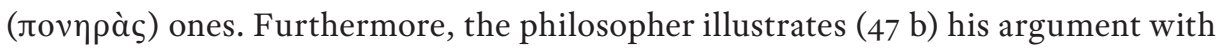
a rather perplexing example, when he points out that an athlete ought to heed the opinion of a doctor or trainer rather than that of just anybody. The problem with the argument is that it does not sit well with Socrates' anti-relativistic stance, for every trainer must be sensitive to the changing circumstances so as to properly adapt the training and adequately assess the progress in the performance of his trainee ${ }^{21}$. After all, efficiency is dependent on the circumstances and what turns out to be the most efficient in one situation may prove drastically inefficient in another. However, Socrates proves undisturbed, as he extrapolates that it cannot be otherwise with "the just and unjust and shameful and

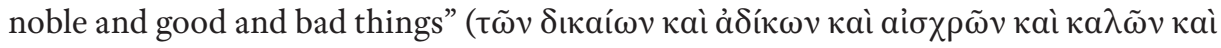

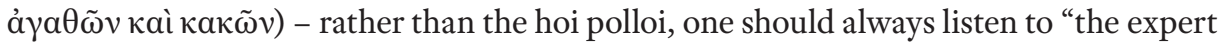

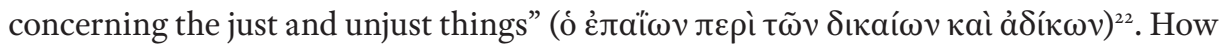
can we account for Socrates' apparently bizarre position?

It seems that the answer lies in Socrates' suggestion that there may be no expert in moral questions at all ${ }^{23}$. Subsequently, the philosopher points out (49 d) that in matters of

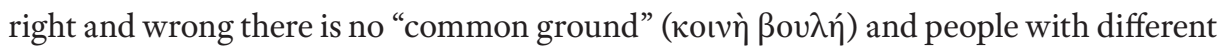

${ }^{20}$ I discuss the issue in Domaradzki 2008.

21 The first one to have noticed this was Greenberg (1965: 55-56).

${ }^{22}$ Cri. $47 \mathrm{c}-48$ a. Translation by West and West (1984: 105-106).

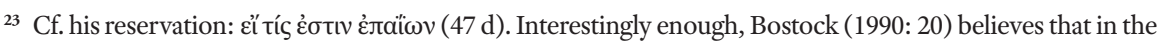
Crito Plato does suggest that "there is such a thing as the moral expert" and that "the laws are the experts". Also Erler (2007: 118) characterizes the laws as "eigentliche Experten" and "unwiderlegliche Fachleute". 


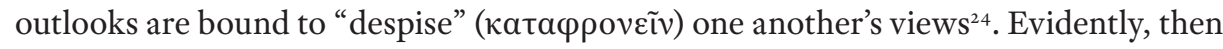
Socrates is aware of the insolubility of axiological controversies ${ }^{25}$, even though he reasons about his civil duties as though there were experts in moral issues ${ }^{26}$. When Socrates denies the existence of any common ground between proponents of different sets of values, he clearly realizes the impossibility of reaching any consensus in his exchange of views with Crito. Nevertheless, the philosopher participates in the discussion, for his primarily concern is to examine the compatibility of a given course of action with the views that are espoused by either of the parties in the dialogue ${ }^{27}$.

The same applies to the discrepancy between the defiant Socrates of the Apology $(29 \mathrm{c}-\mathrm{d})$ and the submissive Socrates of the Crito $(51 \mathrm{~b}-\mathrm{c})$. Plato deliberately creates such contradictions as the one between Socrates' insistence $(28 \mathrm{~b})$ that every man should be exclusively concerned with whether what he does is right or wrong and the Laws' insistence (50 c) that Socrates is bound by an agreement to abide by whatever judgments the city reaches in trails. It is for the same reason that Plato in the Apology (41 c) has Socrates praise the laws of the other world for not sentencing philosophers to death, whereas in the Crito ( 54 c), the Athenian laws are characterized as "brothers" (ả $\delta \varepsilon \lambda \varphi o i)$ of the laws in Hades. All such áropíaı are intended by Plato, inasmuch as they serve the philosophical purpose of examining which course of action ought to be chosen as rational.

\section{Concluding remarks: Plato's consistency}

Socrates does not find the sentence just. This is evident from his observation ( $41 \mathrm{~b})$ that should he find himself in Hades, the philosopher hopes to meet Palamedes, Ajax and

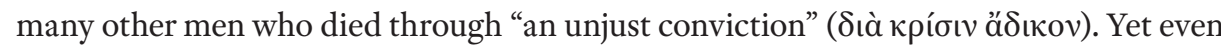
though Socrates in the Apology does not take the court's decision to be fair, Plato has the Laws in the Crito reason that an escape would be equally misguided. Socrates' refusal to escape in the Crito should not be explained in terms of his unconditional observance of the law and unreflective obedience to the state. It seems that through the two dialogues Plato tries to examine the possibility of steering a middle course between encouraging civil disobedience, on the one hand, and embracing relativism, on the other. Thus, the Apology and Crito, illustrate how Plato employs his “deliberative” elenchus so as to investigate both options with equal attentiveness.

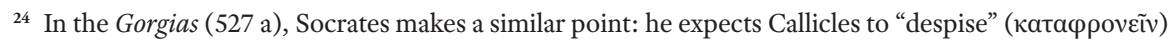
his myth, yet he uses it to persuade the sophist to embrace the view he advocates. Cf. Domaradzki 2008: 24-26.

${ }^{25}$ Socrates' remark that people with different views inevitably despise each other's views shows two important things: firstly, that the option to persuade is not a real option (cf. Miller 1996: 130 and Nails 2009: 15); secondly and relatedly that the philosopher does not really believe in "the possibility of a rational debate with interlocutors who do not share his conviction" (Kahn 1998: 127).

${ }^{26}$ The point has already been made by Gomme (1958: 45). See also Kahn (1998: 103-104), Benson (2000: 28) and Woodruff (2009: 44).

${ }^{27}$ Brickhouse and Smith (1994: 24) aptly call this elenchus “deliberative”. 
Plato's dialogues teem with various inconsistencies and contradictions that have been deliberately created by the philosopher for a very specific reason: they are designed to induce reflection and to persuade the reader into embracing the view of the Platonic Socrates rather than that of the sophists (cf. Domaradzki 2008: 30). In the Apology and Crito, the young Plato presents, such ájopíal, as the ones discussed above, for he continues the ethical task undertaken by Socrates: to teach and educate through philosophy. If Socrates perceived his conversations as a service to the god, then the young Plato must have similarly viewed his dialogues. The Apology ( 38 a) famously condemns "the unexam-

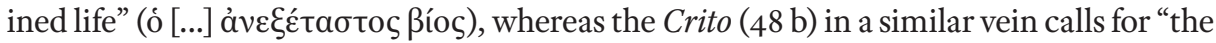

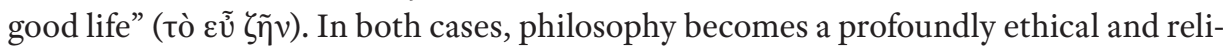
gious commitment, as examining oneself constantly is tantamount to leading a good life.

In the Crito, Socrates calmly awaits death not because the state is superior to its citizens, but rather because the first option of the aforementioned alternative has been exhausted: in the Apology Socrates has failed to persuade the state and in the Crito he must, therefore, obey. If the Apology is taken to illustrate an unsuccessful attempt to persuade the establishment, then the Crito shows the importance of ascertaining what conditions need to be met in order for persuasion to be efficient. When taken together, the Apology and Crito create a dialectic tension, as the young Plato puts forward the question whether it is possible to avoid any pragmatism and the implied relativism, once the doctrine of civil disobedience is rejected. If the conflict between the two dialogues is seen as a clash of disparate life-views, then their common denominator is an exhortation to follow the life of a philosopher. 


\section{REFERENCES}

BArker, A., 1977, Why Did Socrates Refuse to Escape?, Phronesis 22 (1), pp. 13-28.

Benson, H.H., 2000, Socratic Wisdom: The Model of Knowledge in Plato's Early Dialogues, Oxford, Oxford University Press.

Beversuus, J., 2000, Cross-Examining Socrates: A Defense of the Interlocutors in Plato's Early Dialogues, Cambridge, Cambridge University Press.

Boвonich, C., 2008, Plato's Politics, In G. Fine (ed.), The Oxford Handbook of Plato, Oxford, Oxford University Press, pp. 311-335.

Bosтock, D., 1990, The Interpretation of Plato's “Crito”, Phronesis 35 (1), pp. 1-20.

Brickhouse, T.C. And Smith N.D., 1994, Plato’s Socrates, Oxford, Oxford University Press.

Colson, D.D., 1985, On Appealing to Athenian Law to Justify Socrates’ Disobedience, Apeiron 19, pp. $133-151$.

Colson, D.D., 1989, “Crito” 51 A-C: To What Does Socrates Owe Obedience?, Phronesis 34 (1), pp. $27-55$.

Domaradzki, M., 2008, Plato's Ambivalence about Rhetoric in the Gorgias, Eos 95 (1), pp. 19-31.

Dyson, M., 1978, The Structure of the Laws' Speech in Plato's Crito, The Classical Quarterly, 28 (2), pp. 427-436.

Erler, M. ,2007, Platon, In., H. Flashar (ed.), Grundriss der Geschichte der Philosophie. Begründet von Friedrich Ueberweg. Völlig neu bearbeitete Ausgabe. Die Philosophie der Antike, 2/2, Basel, Schwabe Verlag.

Gomme, A.W., 1958, The Structure of Plato’s ‘Crito', Greece \& Rome, 5 (1), pp. 45-51.

Greenberg, N.A., 1965, Socrates' Choice in the Crito, Harvard Studies in Classical Philology, 70, pp. 45-82.

Grube, G.M.A., 1975, Plato: The Trial and Death of Socrates, Indianapolis, Hackett Publishing.

JedAn, C., 2010, Sokrates und die deliberative Demokratie. Zum sokratischen Politikverständnis in Platons Apologie, Kriton und Gorgias, Peitho. Examina Antiqua 1, pp. 31-43.

Kahn, C.H., 1998, Plato and the Socratic Dialogue: The Philosophical Use of a Literary Form, Cambridge, Cambridge University Press.

KierkegaARD, S., 1989, The Concept of Irony with Continual Reference to Socrates, trans. H.V. Hong and E. Hong, Princeton, Princeton University Press.

KLosko, G., 2006, The Development of Plato's Political Theory, Oxford, Oxford University Press.

KraUt, R., 1984, Socrates and the State, Princeton, Princeton University Press.

Miller, M., 1996, “The Arguments I Seem to Hear": Argument and Irony in the "Crito", Phronesis 41 (2), pp. 121-137.

NaILs, D., 2009, The Trial and Death of Socrates, In, S. Ahbel-Rappe, and R. Kamtekar (eds.), A Companion to Socrates, Malden/Oxford, Wiley-Blackwell, pp. 5-20.

Penner, T., 1997, Two Notes on the Crito: The Impotence of the Many, and 'Persuade or Obey', The Classical Quarterly 47 (1), pp. 153-166.

SACCARelli, E., 2007, Alone in the World: The Existential Socrates in the Apology and Crito, Political Studies 55 (3), 522-545.

Sauvé Meyer, S., 2006, Plato on the Law, In., H. Benson (ed.), A Companion to Plato, Oxford, Blackwell, pp. 373-387.

Vlastos, G., 1974, Socrates On Political Obedience and Disobedience, Yale Review 63, pp. 517-534.

Vlastos, G., 1995, The Historical Socrates and Athenian Democracy, In: Gregory Vlastos: Socratic Studies, M. Burnyeat (red.), Cambridge, Cambridge University Press, pp. 87-108.

WALlaCE, R.W., 2011, Plato's Socrates on Obeying the Laws of Democratic Athens, ФI $\Lambda$ ООФІA 41, pp. 87-97. 
Weiss, R., 1998, Socrates Dissatisfied. An Analysis of Plato’s Crito, Oxford, Oxford University Press.

West, T.G. AND West G.S., 1984, Four Texts on Socrates. Plato's Euthyphro, Apology, and Crito and Aristophanes' Clouds, Ithaca-London, Cornell University Press.

West, E.J.M., 1989, Socrates in the Crito: Patriot or Friend? In J.P. Anton \& A. Preus (eds.), Essays in Ancient Greek Philosophy III. Plato, Albany, State University of New York Press, pp. 71-84.

WoodrufF, P. , 2009, Socrates Among the Sophists, In, S. Ahbel-Rappe and R. Kamtekar (eds.), A Companion to Socrates, Malden/Oxford, Wiley-Blackwell, pp. 36-47.

Young, C.M., 2006, The Socratic Elenchus, In., H. Benson, (ed.), A Companion to Plato, Oxford, Blackwell, pp. 55-69.

Zuckert, C.H., 2009, Plato's Philosophers. The Coherence of the Dialogues, Chicago, The University of Chicago Press.

MIKOEA J DOMARADZKI

/Poznań /

\section{Defiance, Persuasion or Conformity? The Argument in Plato's Apology and Crito}

The present paper attempts to throw some light on the conundrum of Socrates' political views in the Apology and Crito. The problem resides in that the Socrates of the Apology evidently undermines the authority of Athenian democracy, whereas the Socrates of the Crito argues that his escape from prison would be tantamount to disrespecting the state, which would in turn threaten the prosperity of the entire лó $\lambda_{1}$. The article suggests that in the two dialogues, the young Plato examines the possibility of steering a middle course between embracing relativism, on the one hand, and encouraging civil disobedience, on the other. Thus, the philosopher focuses primarily on investigating the two options, without either totally subordinating the citizen to the state, or unreflexively accepting any crude pragmatism.

Socrates, Plato, persuasion, relativism, civil disobedience.
KEYWORDS 